\title{
GÊNERO E PRESERVAÇÃO: DIFERENTES EXPRESSÕES NOS MODOS DE MORAR
}

\author{
Thays T. Guimarães*, Sabrina Fontenele
}

\section{Resumo}

A seguinte pesquisa dedica-se ao estudo dos registros das práticas domésticas. O estudo é feito através da análise de três espaços distintos: a sede do Centro de Preservação Cultural da Usp (antiga Casa de Dona Yayá), o Museu Frida Kahlo e a E1027, situadas no Brasil, no México e na França, respectivamente. Os ambientes em que as residências mencionadas estão inseridas são contextualmente e fisicamente distintos. Através desta pesquisa, percebe-se que a discussão de gênero é intrínseca à construção do espaço doméstico. Assim, procura-se entender a narrativa construída em cada uma das residências uma vez que elas mostram muito dos rituais e modos de pensar e viver de suas habitantes. Foram escolhidas residências da primeira metade do século XX, devido às notáveis mudanças nos padrões de organização doméstica e do papel das mulheres nestes ambientes internos - período também de ingresso das mulheres no domínio público. Para avançar a discussão sobre a pequena porcentagem de mulheres dentre as personalidades que tiveram suas trajetórias celebradas através de museus-biográficos, a pesquisa se apresenta sob a perspectiva de mulheres que criam novos modelos de espaços domésticos sejam elas arquitetas ou usuárias.

\section{Palavras-chave:}

Gênero, preservação, memória.

\section{Introdução}

Esse projeto levantou a biografia das três mulheres centrais: Dona Yayá, Frida Kahlo e Eileen Gray e os momentos de exposição delas e de suas casas, uma vez que tanto elas quanto suas residências são muito conhecidas atualmente. Foram levantados aspectos de conservação e restauro, contexto urbano, domesticidade e questões de gênero bem como informações sobre a gestão atual desses espaços. Foram pesquisados os objetivos culturais do órgão gestor, as atividades, exposições e intervenções realizadas, os aspectos de conservação e a relação do imóvel com os grupos externos de visitantes e pesquisadores.

\section{Resultados e Discussão}

A preservação dessas casas históricas mostrou como cada residência implicou em diferentes formas de prazer, repouso, evasão ou reclusão e qual a noção de conforto expressa em cada uma: seja para resguardo psíquico, emocional ou corporal. Foram analisadas as dimensões e organização dos cômodos, sua funcionalidade, comodidade e conveniência corporal e psíquica. Através de um estudo de gênero, percebe-se que todas as três mulheres experimentaram formas não convencionais de "habitar" questionando os papeis sociais e de gênero e como a preservação contribuiu para expandir a memória delas dentro do campo da arquitetura.

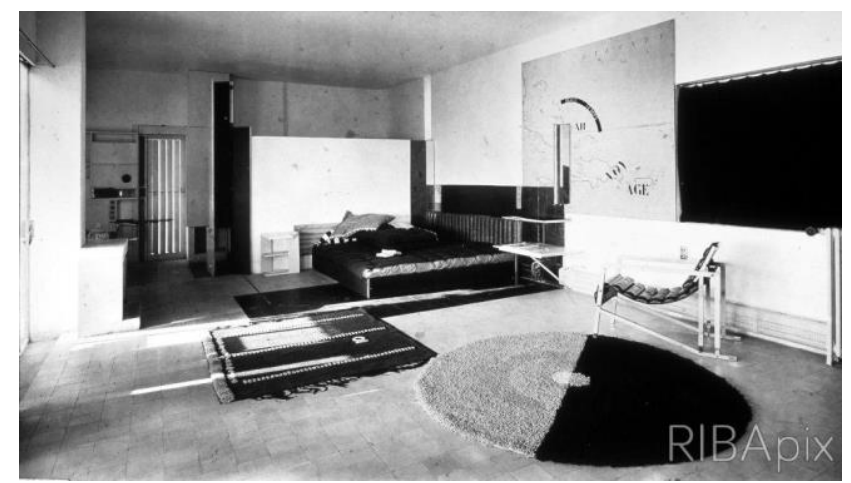

Figura 1. Sala de estar E1027, fotografia de Eileen Gray 1929.
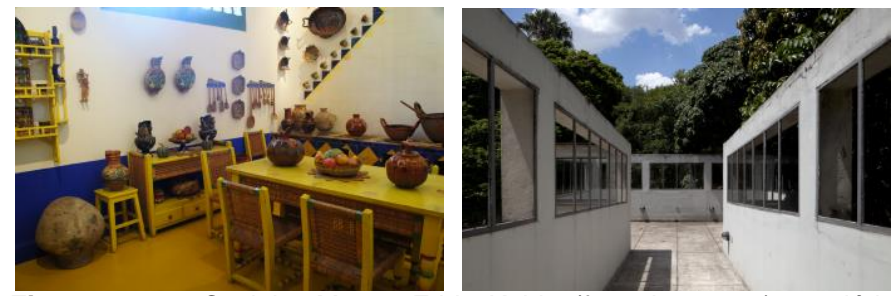

Figura 2 e 3. Cozinha Museo Frida Kahlo (foto da autora) e solário Casa da Dona Yayá (foto de Eduardo Costa).

\section{Conclusões}

Foram levantadas questões sobre a construção da memória, modos de morar e estudos sobre formas de preservação de residências e lugares de memória. Percebi a necessidade de encontrar uma leitura mais positiva e produtiva de quem foram estas mulheres. As três residências são amplamente diferentes em questões de domesticidade, preservação e usos: experimentação de diferentes modos de morar, criação de narrativas e histórias sobre a mulher - artista, moderna, solteira, burguesa. Ampliou-se também o debate sobre os processos de conservação e intervenção, através de uma análise do programa expográfico e das instituições que gerenciam esses espaços. Percebi os desafios de ocupar bens tombados e promover novos usos relacionados tanto ao patrimônio cultural e a lembrança dos moradores e lidar com questões ainda pouco discutidas como gênero, saúde mental e modos de morar. A pesquisa analisou como todas estas questões podem e são tratadas atualmente tendo a casa como suporte.

\section{Agradecimentos}

Meus agradecimentos mais queridos à minha orientadora, Sabrina.

Instituição de fomento: FAPESP/PIBIC-CNPq

1CARVALHO, Vânia. Gênero e artefato: o sistema doméstico na perspectiva da cultura material - São Paulo 1870-1920. São Paulo: Editora Edusp/Fapesp, 2008.

${ }^{2}$ COLOMINA, Beatriz. Sexuality and space. Nova lorque: Princeton Architectural Press, 1992 